\title{
SOMATOTYPE OF YOUNG FEMALE VOLLEYBALL PLAYERS
}

\author{
Mirjana Milić*, Zoran Grgantov and Ratko Katić \\ Faculty of Kinesiology, University of Split, Croatia
}

\begin{abstract}
The aim of this study was to compare the somatotype of youth Croatian female volleyball players (mean age 14.05 years) in terms of playing performance. All players evaluated were classified into a less successful group $(\mathrm{N}=53)$ and a group of more successful players $(\mathrm{N}=61)$. The somatotype means of the whole sample were $4.41-2.79-3.68 \pm 1.02-1.04-1.29$, of less successful players $4.69-2.94-3.40 \pm 0.95-0.96-1.21$, and of more successful players $4.17-$ $2.69-3.87 \pm 1.03-1.07-1.30$. Based on a Category Chart, 7 somatotype categories were obtained. A significantly higher proportion of balanced ectomorph somatotype category was established in more successful players, and a significantly higher proportion of ectomorphicendomorph somatotype category was found in less successful players.
\end{abstract}

Keywords: anthropometric characteristics, Heat-Carter, playing performance, volleyball

\section{Introduction}

Analysis of the body build structure, shape and composition of athletes in different sports and their relation to sport success has been an area of great scientific interest for a long time. The height of the net separating the opponent teams, small dimensions of the court, great ball speed and specific game techniques characterize volleyball as a sports game. These specificities also condition the specificities in body build which are necessary for successful performance of different movement structures in competitions (sprinting, direction of movement changes, jumps, landings...). Somatotyping is one of the most frequently used techniques for analyzing the body build. Because of its uniqueness, somatotyping has been used to study many aspects of exercise, sports sciences and human biology, which may be important in identifying talented young athletes for particular sports (Carter, Ackland, Kerr, \& Stapff, 2005).

In volleyball, somatotyping has been used for comparing senior female volleyball players to female athletes in other sports (Bayios, Bergeles, Apostolidis, Noutsos, \& Koskolou,. 2006), but also for analyzing the differences between female senior volleyball players regarding player positions and/or competitive successfulness (Gualdi-Russo, \& Zaccagni 2001, Esper 2004, Malousaris, Bergeles, Barzouka, Bayios, Nassis, \& Koskolou 2008, Carvajal, Betancourt, León, Deturnel, Martínez, Echevarría, Castillo, \& Serviat 2012).

\footnotetext{
* Corresponding author. Faculty of Kinesiology, University of Split, Teslina 6, 21000 Split, Croatia, e-mail: mirjanam@kifst.hr
} 
A great number of somatotype research studies have also been conducted on samples of young female volleyball players from different countries (Riegerova, \& Ryšavy, 2001, Duncan, Woodfield, \& Al-Nakeeb 2006, Soares, \& De Paula 2006, Dostalová, Riegerová, \& Přidalová 2007, De Hoyo, Corrales, \& Paez 2008, B.G. Cabral, S.A. Cabral, Batista, Fernandes Filho, \& Knackfuss 2008, Ayan, Bektas, \& Ali Emre 2012). Differences between young volleyball players regarding player positions were analyzed in some of these studies, but the authors were not able to find a single research in which differences in somatotype had been analyzed in relation to player quality of young female volleyball players. Moreover, most of these studies were conducted on relatively small subject samples.

Considering the abovementioned shortcomings of previous research conducted on a sample of young female volleyball players, the main goal of this research is to analyze the differences in frequency of each somatotype category between less successful and more successful female volleyball players using a larger subject sample.

\section{Method}

Somatotype data were collected on 114 young female volleyball players, members of 6 clubs from the Dalmatia region, of average chronological age of 14.06 \pm 0.96 , average height of $170.22 \pm 7.06 \mathrm{~cm}$ and body mass of $58.35 \pm 8.35 \mathrm{~kg}$. With the purpose of calculating the somatotype (by Heat-Carter method), 10 anthropometric measures were measured: height and mass; triceps, subscapular, supraspinale and calf skinfolds; flexed arm and calf girth; humerus and femur breadth (Carter, \& Heath, 1990).

Player quality on a five-point Likert represents a criterion variable. A grade of 1-5 was assigned to each player regarding 2 criteria (Table1):

1. Team ranking in the competition: All teams participated in the Croatian regional championship and, based on their ranking in the championship, they were classified into 3 categories $\left(1^{\text {th }}-4^{\text {th }}\right.$ place; $5^{\text {th }}-8^{\text {th }}$ place; $9^{\text {th }}-12^{\text {th }}$ place)

2. Player quality within the team (assessed by the coaches). Each coach divided the players of her/his team into 3 groups (the most successful - the most efficient players, average - other members of the starting line-up and reserves who contribute to game quality; the least successful - players who very rarely or never enter the game)

All players who were assigned grades of 1-3 were categorized into the less successful group, and all players who were assigned grades 4 and 5 were categorized into the group of more successful.

Table 1

Categorization of individual player performance level

\begin{tabular}{ccccc}
\hline \multirow{2}{*}{$\begin{array}{l}\text { Competition } \\
\text { ranking }\end{array}$} & $\begin{array}{c}\text { Individual performance level } \\
\text { Members of the } \\
\text { national team }\end{array}$ & $\begin{array}{c}\text { The most } \\
\text { successful players } \\
\text { in the team }\end{array}$ & $\begin{array}{c}\text { Average } \\
\text { players in the } \\
\text { team }\end{array}$ & $\begin{array}{c}\text { The least } \\
\text { successful players } \\
\text { in the team }\end{array}$ \\
\hline $1-4$ & 5 & 5 & 4 & 3 \\
$5-8$ & 5 & 4 & 3 & 2 \\
$9-12$ & 5 & 3 & 2 & 1 \\
\hline
\end{tabular}


The data was analyzed by first calculating the basic descriptive indicators of the 10 morphological measures, as well as 3 somatotype components (arithmetic mean and standard deviation), separately for the whole sample and for more successful and less successful players. Then, each volleyball player was classified into one of the 13 possible somatotype categories. In such a way, 7 somatotype categories were obtained. Frequency and percentage of each category were calculated within the whole sample, as well as in the subsamples of less successful and more successful players. Analysis of differences in proportions was used to establish whether there were significant differences in frequency of each somatotype category between the less successful and more successful players. In order to emphasize the differences of somatotype between player positions, along with the profile of the whole sample and of the subsamples, 2 player profiles were singled-out of players who are members of the youth Croatian national team (one playing the middle hitter position, and the other playing libero).

By using the Somatotype software, subjects were classified according to somatotype categories, while statistical data analysis was conducted by using the Statistica Ver 10.00 software.

\section{Results}

Descriptive statistics results of morphological variables of 114 young female volleyball players are presented in Table 2. The analysis of distribution parameters shows that all variables are normally distributed and that there are no deviations from normal distribution. Normality of distribution was tested by using a Kolmogorov-Smirnov test with a critical value of 0.13 .

Young female volleyball players tested in this research were on average $5 \mathrm{~cm}$ taller and 3 $\mathrm{kg}$ heavier than 152 female students of primary school Bijaći from Kaštela and 25 Croatian female karateka of approximately the same age tested in the research conducted by Katić, Jukić, \& Milić (2012). In comparison to female handball players of the same age (Zapartidis, Vareltzis, Gouvali, \& Kororos, 2009), female volleyball players tested here are averagely $6 \mathrm{~cm}$ taller, but with the same body mass. This points to the importance of body height for success in volleyball, and of muscle mass for success in handball. Such results are to be expected because the net separating the opponent teams in volleyball prevents contact between the players. Therefore, prominent muscle mass is not necessary, and due to the height of the net, taller players have an advantage during blocking and spiking.

Table 2

Descriptive statistics of variables of morphological characteristics in young female volleyball players $(N=114)$

\begin{tabular}{lccccc}
\hline Variables & Median & Mean & SD & Range & KS \\
\hline Height & 170.35 & 170.22 & 7.06 & $154.2-193.1$ & 0.05 \\
Mass & 57.10 & 58.35 & 8.35 & $37.4-80.6$ & 0.05 \\
Triceps SF & 17.27 & 17.27 & 4.79 & $9-30.27$ & 0.07 \\
Subscapular SF & 10.07 & 10.53 & 3.02 & $5.47-20.13$ & 0.10 \\
Supraspinale SF & 15.62 & 16.26 & 5.10 & $6.07-35.73$ & 0.07 \\
Calf SF & 14.50 & 15.19 & 4.52 & $6.73-27.4$ & 0.07 \\
Arm & 26.00 & 25.96 & 2.41 & $16.26-31.4$ & 0.06 \\
Calf Girth & 34.45 & 34.24 & 2.53 & $27.7-41$ & 0.06 \\
Humerus B & 6.10 & 6.13 & 0.31 & $5.4-7.3$ & 0.09 \\
Femur B & 9.20 & 9.21 & 0.40 & $8.4-10.4$ & 0.06 \\
\hline & & & & & Test $=0.13$ \\
\hline
\end{tabular}

LEGEND: Median - central value, Mean - mean, SD - standard deviation, Range - the lowest and the highest value, KS - KolmogorovSmirnov test 
As it can be seen in Table 3, all somatotype components are averagely expressed (within the range of 2.5 to 5) in the whole sample as well as in the subsamples of less successful and more successful volleyball players. The endomorph somatotype component is dominant in all samples, while the mesomorph component is the least expressed one. Given the values of each somatotype component, young female volleyball players averagely fit the ecomorphicendomorph category, the subsample of more successful players averagely fits the ectomorphendomorph category, and less successful players fit the balanced endomorph category.

The abovementioned categories were obtained based on mean values of the larger number of players in each somatotype component. The main problem is that such an approach does not allow insight into the somatotype specificities of individual players, i.e. it does not provide information about individual classification of players into somatotype categories.

Table 3

Descriptive indicators of somatotype components of the whole sample, less successful and more successful female volleyball players

\begin{tabular}{lcccccc}
\hline \multirow{2}{*}{$\begin{array}{l}\text { Somatotype } \\
\text { components }\end{array}$} & \multicolumn{2}{c}{ Total sample $(\mathrm{N}=114)$} & \multicolumn{2}{c}{ Less successful $(\mathrm{N}=53)$} & \multicolumn{2}{c}{ More successful (N=61) } \\
\cline { 2 - 7 } & $\mathrm{M}$ & $\mathrm{SD}$ & $\mathrm{M}$ & $\mathrm{SD}$ & $\mathrm{M}$ & $\mathrm{SD}$ \\
\hline Endomorphy & 4.42 & 1.02 & 4.69 & 0.95 & 4.17 & 1.03 \\
Mesomorphy & 2.81 & 1.03 & 2.94 & 0.96 & 2.69 & 1.07 \\
Ectomorphy & 3.66 & 1.28 & 3.40 & 1.21 & 3.87 & 1.30 \\
\hline
\end{tabular}

LEGEND M - mean, SD - standard deviation

Therefore, classification of players into somatotype categories was calculated separately for each player, as can be seen in Table 4. Frequency $(\mathrm{N})$ and percentage (\%) of each somatotype category was calculated for the whole sample, as well as for the subsamples of more successful and less successful players, along with the significance of differences in proportions of each category in the subsamples of less successful and more successful female volleyball players (p).

Table 4

Frequency and percentage of each somatotype category and significance of differences in proportions between less successful and more successful female volleyball players

\begin{tabular}{lccccccc}
\hline \multirow{2}{*}{ Somatotype category } & $\begin{array}{c}\text { Total sample } \\
(\mathrm{N}=114)\end{array}$ & $\begin{array}{c}\text { Less successful } \\
(\mathrm{N}=53)\end{array}$ & $\begin{array}{c}\text { More successful } \\
(\mathrm{N}=61)\end{array}$ & $\mathrm{p}$ \\
\cline { 2 - 7 } & $\mathrm{N}$ & $\%$ & $\mathrm{~N}$ & $\%$ & $\mathrm{~N}$ & $\%$ & \\
\hline Endomorph-ectomorph & 19 & 16.67 & 10 & 18.87 & 9 & 14.75 & 0.278 \\
Ectomorphic endomorph & 15 & 13.16 & 12 & 22.64 & 3 & 4.92 & 0.003 \\
Balanced endomorph & 7 & 6.14 & 5 & 9.43 & 2 & 3.28 & 0.086 \\
Mesomorphic endomorph & 28 & 24.56 & 14 & 26.42 & 14 & 22.95 & 0.334 \\
Mesomorph-endomorph & 5 & 4.39 & 2 & 3.77 & 3 & 4.92 & 0.383 \\
Balanced ectomorph & 33 & 28.95 & 5 & 9.43 & 28 & 45.9 & 0.000 \\
Central & 7 & 6.14 & 5 & 9.43 & 2 & 3.28 & 0.086 \\
\hline
\end{tabular}

LEGEND: N-subject frequency, \%- relative values, p-significance of differences in proportions between less successful and more successful female volleyball players 
Based on a Category Chart, 7 somatotype categories were obtained (table 3). Most of the young female volleyball players fit the categories of balanced ectomorph (29\%) and mesomorphic endomorph (25\%).

The highest percentage of more successful volleyball players (46\%) fits the balanced ectomorph category, followed by the mesomorphic endomorph category (23\%). Less successful players, in the highest percentage, fit the somatotype categories of mesomorphic endomorph (26\%), ectomorphic endomorph (23\%) and endomorph ectomorph (19\%). By analysis of differences in proportions between less successful and more successful young female volleyball players, a significantly higher proportion of the balanced ectomorph somatotype category was established in more successful players, and a significantly higher proportion of the ectomorphicendomorph somatotype category was found in less successful players.

The somatoplot (Figure 1) shows mean values of somatotype for the whole sample, subsamples of more successful and less successful players, as well as individual somatoplots of young female volleyball players. Also, 2 somatoplots of the most successful players (Croatian national team members) who play the positions of libero and middle hitter were singled-out from individual somatoplots.

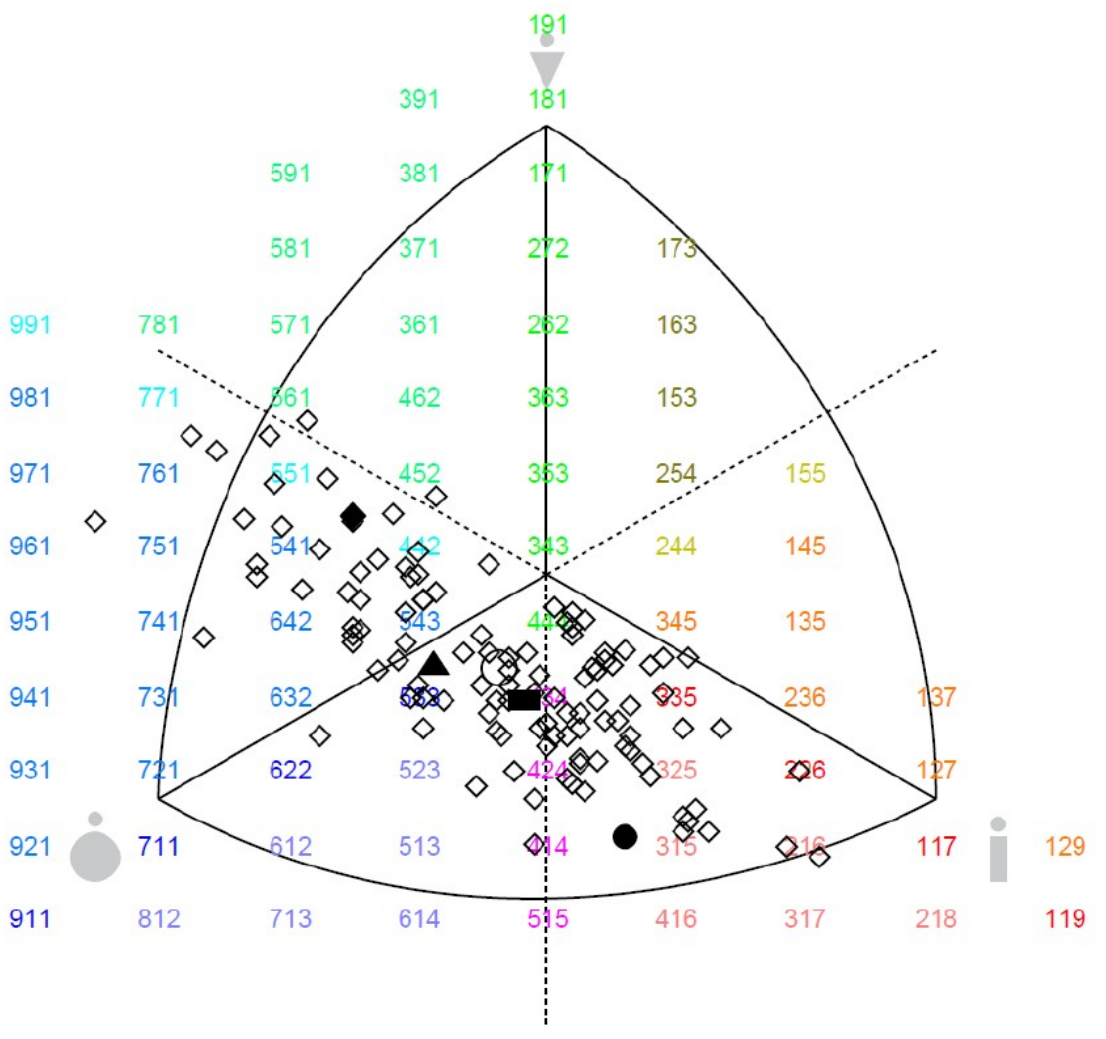

\footnotetext{
Legend: $-\quad$ mean of the whole sample (4.4 2- 2.81 - 3.66)

mean of less successful players, (4.69-2.94-3.40)

mean of more successful players, (4.19 -2.69 -3.87)

libero - national team member $(4.9-4.5-2.5)$

middle hitter - national team member $(3.9-1-5.1)$

somatoplots of individual players
}

Figure 1 Somatoplot of young female volleyball players 


\section{Discussion}

After examining the mean somatotypes of the subsamples of young female volleyball players with different performance levels (Table 3), it can be noticed that there is a trend of a decreased endomorph component and an increased ectomorph somatotype component among more successful players. This indirectly indicates that a relatively small body mass in relation to body height is required in volleyball. The dominance of the endomorph component can even in more successful players be partly explained by characteristics of the sample which was composed of female volleyball players at the lower (club) performance level. Namely, in most somatotype studies conducted among young female volleyball players with the national team quality level, the dominance of the ectomorph somatotype component has been established. For example, Cabral et al. (2008) obtained mean somatotype values of $3.1-2.2-3.9$ on a sample of 14 young female Brazil national team members of average age of 15.9, and Ayan et al. (2012), using a sample of 58 young female Turkish volleyball players who received invitations to the representative camp, established mean somatotype values of $3.4-2.1-4.5$. On the other hand, the dominance of the endomorph somatotype component in the whole sample indirectly indicates the problem of excessive subcutaneous fat tissue in some volleyball players, which has also been noticed in some previous studies involving the sample of young female Croatian volleyball players (Grgantov, Katić, \& Janković, 2006).

Analysis of the somatotype categories (Table 4) enables a more precise insight into the differences in body build between more successful and less successful female volleyball players. A significantly higher frequency of somatotype predominated by the ectomorph component, with balanced development of the endomorph and mesomorph somatotype component (balanced ectomorph category) in successful volleyball players, is in accordance with the aforementioned research conducted on samples of young female national level volleyball players. Such body build is especially suitable for those volleyball elements which are performed above the net (spiking and blocking). These elements are characteristic for all player positions in volleyball, except for libero and, to some extent, for setter, and through their successful performance, a team can win most points in a competition.

On the other hand, the dominance of the endomorph somatotype component, with a less expressed mesomorph component (ectomorphic-endomorph category) is significantly more frequent in less successful volleyball players. It is evident that excessive subcutaneous fat tissue, along with the lack of body mass, has a negative impact on agility and explosiveness in young female volleyball players. Low level of these motor abilities hinders successful performance of most movement structures in volleyball (sprinting, direction of movement changes, jumping, hitting, landings...), and therefore successful performance of all technical-tactical elements.

The mesomorphic-endomorph somatotype category is characteristic for over $20 \%$ of players in both subsamples. It can be assumed that players in the more successful subsample are mostly libero players who compensate their somewhat more expressed endomorph somatotype component with, for example, well developed motor abilities, technical-tactical skills or intellectual abilities and personality traits. The fact that relatively short, but strong players, who are also efficient in a setter position or even an outside hitter position, can be seen in the younger age groups in competitions must not be disregarded.

The abovementioned, and particularly the presented differences in the mean somatotype between the two young Croatian national team members who play the libero and middle hitter positions (Figure 1), indicate the necessity for further analysis of somatotype of young female volleyball players in different player positions. 


\section{References}

Ayan, V., Bektas, Y., \& Ali Emre E. (2012). Anthropometric and performance characteristics of Turkey National U-14 volleyball players. African Journal for Physical, Health Education, Recreation and Dance, 18(2), 395-403.

Bayios, I. A., Bergeles, N. K., Apostolidis, N. G., Noutsos, K.S., \& Koskolou M. B. (2006). Anthropometric, body composition and somatotype differences of Greek elite female basketball, volleyball and handball players. Jurnal of Sports Medicine and Physical Fitness, 46(2), 271-280.

Cabral, B. G., Cabral, S. A., Batista, G. R., Fernandes Filho, J., \& Knackfuss, M. I. (2008). Somatotype and anthropometry in brazilian national volleyball teams. Motricidade, 4(1), 67-73.

Carter, J. E .L., Ackland, T. R., Kerr, D. A., \& Stapff, A. B. (2005). Somatotype and size of elite female basketball players. Journal of Sports Sciences, 23(10), 1057-1063.

Carter, J. E. L., \& Heath, B. H. (1990). Somatotyping: Development and Applications. New York: Cambridge University Press.

Carvajal, W., Betancourt, H., León, S., Deturnel, Y., Martínez, M., Echevarría, I., et al. (2012). Kinanthropometric profile of Cuban women Olympic volleyball champions. MEDICC Revision, 14(2), 16-22.

De Hoyo, M., Corrales, B. S., \& Paez, B. S. (2008). Determinación del somatotipo En jugadores infantiles de voleibol: validez como criterio de selección de jóvenes talentos. Revista Brasileira de Cineantropometria \& Desempenho Humano, 10(3), 255-260.

Dostálová I., Riegerová, J., \& Přidalová, M. (2007). Body composition of young volleyball players. 5th International Conference Movement and Health 2007. Vlasta Karásková, Olomouc, 42.

Duncan, M. J., Woodfield, L., \& Al-Nakeeb, Y. (2006). Anthropometric and physiological characteristics of junior elite volleyball players. British Journal of Sports Medicine, 40(7), 649-651.

Esper, A. (2004). Mediciones antropométricas en jugadoras argentinas de voleibol de primera división. Revista digital de Educación Física y Deportes, 10(76).

Grgantov, Z., Katić, R., \& Janković, V. (2006). Morphological characteristics, technical and situation efficacy of young female volleyball players. Collegium Antropologicum, 30(1), 87-96.

Gualdi-Russo E., \& Zaccagni, R. (2001). Somatotype, role and performance in elite volleyball players. Journal of Sports Medicine and Physical Fitness, 41(2), 256-262.

Katić R., Jukić, J., \& Milić, M. (2012). Biomotor status and kinesiological education of students aged 13 to 15 years - example: karate. Collegium Antropologicum, 36 (2), 555-562.

Malousaris, G. G., Bergeles, K. B. N. K., Barzouka, K. G., Bayios, I. A., Nassis, G. P., \& Koskolou, M.D. (2008). Somatotype, size and body composition of competitive female volleyball players. Journal of Science and Medicine in Sport, 11, 337-344.

Riegerová, J., \& Ryšavý, J. (2001). Somatodiagnostics of female, secondary school age volleyball players. Gymnica, 31(1), 37-42. 
M. Milić, Z. Grgantov and R. Katić

Soares, C. A., \& De Paula, A. H. (2006). Análise do perfil cineantropométrico de jovens praticantes de voleibol na faixa etária de 12 a 15 anos. Movimentum-Revista Digital de Educação Física, 1, 1-15.

Zapartidis, I., Vareltzis, I., Gouvali, M., \& Kororos, P. (2009). Profile of young handball players by playing position and determinants of ball throwing velocity. Open Sports Sciences Journal, (2), 22-28. 